\title{
Archaeological and Historical Investigations in Bastrop and Lee Counties, Texas
}

Thomas C. Kelly

Erwin Roemer, Jr.

Follow this and additional works at: https://scholarworks.sfasu.edu/ita

Part of the American Material Culture Commons, Archaeological Anthropology Commons, Environmental Studies Commons, Other American Studies Commons, Other Arts and Humanities Commons, Other History of Art, Architecture, and Archaeology Commons, and the United States History Commons

Tell us how this article helped you.

This Article is brought to you for free and open access by the Center for Regional Heritage Research at SFA ScholarWorks. It has been accepted for inclusion in Index of Texas Archaeology: Open Access Gray Literature from the Lone Star State by an authorized editor of SFA ScholarWorks. For more information, please contact cdsscholarworks@sfasu.edu. 
Archaeological and Historical Investigations in Bastrop and Lee Counties, Texas

Creative Commons License

(c) (i) (8)

This work is licensed under a Creative Commons Attribution-NonCommercial 4.0 International License 


\title{
ARCHAEOLOGICAL AND HISTORICAL INVESTIGATIONS IN BASTROP AND LEE COUNTIES, TEXAS
}

\author{
THOMAS C. KELLY \\ and
} ERWIN ROEMER, JR.

WITH A PROJECT SUMMARY BY THOMAS R. HESTER

\author{
Center for Archaeological Research \\ The University of Texas at San Antonio \\ Archaeological Survey Report, No.IOI \\ 1981
}





\title{
UTSA - Center for Archaeological Research
}

\section{ARCHAEOLOGICAL AND HISTORICAL INVESTIGATIONS IN \\ BASTROP AND LEE COUNTIES, TEXAS}

\author{
Thomas C. Kelly \\ and \\ Erwin Roemer, Jr.
}

with a Project Summary by Thomas R. Hester

Center for Archaeological Research

The University of Texas at San Antonio

Archaeological Survey Report, No. 101 


\section{ABSTRACT}

This reconnaissance-level cultural resources survey of 1900 acres in northern Bastrop County, including a small area in Lee County, Texas, was accomplished by the Center for Archaeological Research, The University of Texas at San Antonio, in July 1980. City Public Service (CPS) of San Antonio has proposed a lignite mining project in the area, and this represents the first attempt to determine the nature of the cultural resources and the problems they might present in developing the lignite deposits. Prehistoric resources in the primary area were scarce and of limited significance, but three sites on the west side of the area are considered to be of high potential and may fall within the CPS area of interest. Four historic sites were recorded, eventually, and specific recommendations were made for each. Recommendations were made for future investigations in the area. Where possible, comparisons are made between the present survey and an intensive study, conducted by the Texas Archeological Survey, of the nearby Camp Swift area. 
TABLE OF CONTENTS

Page

Abstract ............................ i

List of figures ......................... ...

Project Summary .................... iv

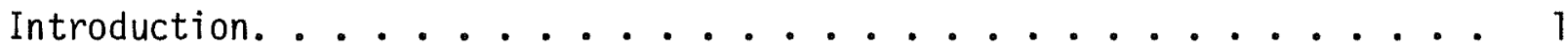

Previous Work in the Area ................ 1

Archaeological Background ................. 1

CPS Study Area A. .................. 3

Methodology .................... 4

Prehistoric Sites................. 5

Prehistoric Sites Outside CPS Study Area A. . . . . . . . . . . 7

Prehistoric Site Summary. . . . . . . . . . . . . 12

Comparisons with the Camp Swift Survey. . . . . . . . . . . 12

Previous Historical Work in the Area. . . . . . . . . . 13

Historic Sites.......................... 14

Historical Comparisons with the Camp Swift Survey . . . . . . . 20

Acknowledgments . . . . . . . . . . . . 22

References Cjted ..................... 23

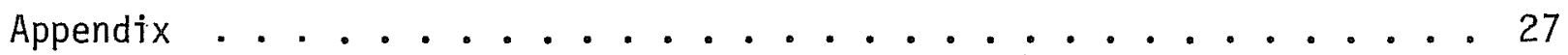




\section{LIST OF FIGURES}

Page

Figure 1. CPS-Butler Area Survey . . . . . . . . . . . 2

Figure 2. John Weaver Collection .............. 8

Figure 3. John Weaver Collection ............. 10

Figure 4. Morgan Chapel Cemetery ............... 16

Figure 5. Morgan Chapel Cemetery ............... 17

Figure 6. Historic Sites ................ . 19

Figure 7. Historic Site 41 BP 202................ 21 
PROJECT SUMMARY

This report presents the results of a reconnaissance-level archaeological study carried out by the Center for Archaeological Research on behalf of City Public Service of San Antonio. Prior to the award of a contract and initiation of field work, the Principal Investigator (TRH) and Co-Principal Investigator (Jack D. Eaton) held meetings with representatives of City Public Service. In one lengthy meeting, the various types of archaeological studies required under state and federal regulations were fully outlined. In addition, a discussion of the possible sequence of archaeological studies and the cost-time effectiveness of each type of study was thoroughly discussed. It was decided that an initial study at the level of an archaeological reconnaissance would be done. This would entail an assessment of the kinds of sites and the potential archaeological problems that might confront City Public Service during its planning phases. At the time, City Public Service owned or had access to 1900 acres in Bastrop County and a smal1 portion in adjoining Lee County. Further land acquisitions were contemplated as part of a planned lignite mining project. It was felt by all who attended the pre-contract meeting that a reconnaissance-level study would benefit both the City Public Service planners and the archaeologists. The archaeological team would gain a better understanding of the nature of sites in the area as well as any difficulties in assessment that might be related to topography and vegetation cover. City Public Service could then gauge how their planning, and eventually, their project, might affect, and in turn be affected by, the presence of historic and prehistoric archaeological sites.

With this clear understanding of City Public Service planning needs and archaeological investigative objectives, field work was carried out in July, 1980. The results of these studies are detailed in this report.

For purposes of planning by City Public Service, several positive statements can be made, reflecting the accomplishments of the archaeological studies:

(1) Two prehistoric sites (41 BP 199 and 41 LE 63) were documented within the 1900 acres designated as CPS Study Area A. None meet National Register criteria. No further investigations are deemed necessary at these sites;

(2) One site (41 BP 204) was found within an additional area of CPS interest (Study Area B). If land modifications are planned for the area, this site should be test-excavated to assess its National Register potential;

(3) Prehistoric sites 41 BP 205 and 41 BP 206 are outside of areas of immediate concern to CPS. As is common in a reconnaissance-level study, they were recorded as part of cultural resource assessment. Both sites have indications of cultural significance and should be tested for National Register evaluation if City Public Service acquires the property and includes it within the proposed lignite project.

(4) Vegetation did obscure, to a certain extent, ground surface visibility in portions of the study area. Since the July, 1980 research was a reconnaissance (not a 100\% intensive survey), it cannot be stated, in an unequivocal fashion, that all sites were recorded. It is likely, given the nature of the recorded sites and their topographic setting (outlined in the report), that no additional sites of significance will be found. But, because of ground cover problems, this statement should be taken as an opinion and not as an absolute statement; 
(5) Four Anglo-European sites of the historic period were recorded within the study area. Three of these (41 BP 201-203) are fairly recent (1ess than 100 years old) houses and outbuildings and are not of National Register potential. The Texas Historical Commission can review these assessments to see whether or not that agency concurs with our evaluations. A fourth historic site (41 BP 200) is the Morgan Chapel Cemetery. City Public Service planners have just recently informed us that the proposed lignite project may impact this cemetery. They are planning to proceed with relocation efforts as prescribed by Texas law (see Guidelines for Archeological Investigation of Mining Areas in Texas, Texas Historical Commission, March, 1987, p. 2). Our summary conclusions for the four historic sites are that, aside from the Morgan Chapel Cemetery, no additional investigations are required.

As planning proceeds on this proposed lignite project, additional archaeological studies may be necessary, as detailed in the pre-contract meeting. The reconnaissance has shown that the upland areas are unlikely to have any significant prehistoric sites. However, as more land is acquired and further planning is initiated, additional reconnaissance or intensive $100 \%$ survey of selected areas should be done in order to confirm this evaluation. The reconnaissance has also clearly indicated, and this is backed up by data from the Camp Swift survey (as discussed in the body of the report), that potentially important prehistoric sites are likely to be concentrated within 200 meters of stream channels, particularly Big Sandy creek. This is an important observation, and one that should be integrated into the long-range planning (in terms of time constraints and project costs) of the proposed lignite mining. All of these factors were discussed at length with CPS planners in a post-fieldwork meeting.

The assessment of cultural resources in the areas proposed for lignite mining requires the continuing interaction of City Public Service planners and qualified archaeologists. We feel that a very good start has been made in this regard-with a pre-contract meeting, a post-fieldwork meeting, and the careful review of the draft of this report by staff members at City Public Service. Such integrated collaborative efforts should insure that cultural resources will be properly evaluated and protected (where necessary). At the same time, the planning and implementation of a needed lignite mining endeavor will be able to proceed.

Thomas R. Hester

February 18, 1981 


\section{INTRODUCTION}

In July 1980, City Public Service (CPS) of San Antonio contracted with the Center for Archaeological Research at The University of Texas at San Antonio to perform a reconnaissance-level archaeological and historical survey of approximately 1900 acres in Bastrop and Lee Counties. CPS designated this area as Study Area A (Fig. 1). CPS owns or controls this area for planned lignite mining. Area A has a buffer zone or zone of interest of approximately 2000 acres which surrounds this area. This buffer zone is scheduled for later survey but is not presently owned by CPS. Ten person days were allocated for the field survey, and 20 person days for research and writing. Roemer prepared the section entitled "Previous Historical Work in the Area"; the remainder was written by Kelly.

\section{PREVIOUS WORK IN THE AREA}

A file search at the Texas Archeological Research Laboratory (TARL), Austin, failed to reveal any recorded archaeological or historical sites in the survey area. Moore (1973:258), in a compilation of Bastrop County cemeteries, does not list any cemeteries in the survey area; however, the current investigations recorded the Morgan Chapel cemetery. Approximately 300 acres of Study Area A are in Lee County, and no references were found pertaining to this small area.

An intensive survey of far greater scope than the present study has recently been reported for Camp Swift (Skelton and Freeman 1979), which lies immediately south of the towns of McDade and Butler, with the CPS area being north of the towns and separated by approximately three miles. The major drainage common to both areas is Big Sandy Creek.

The two surveys should be complementary; thus we have treated this research as an extension of the Camp Swift survey, avoiding as much duplication as possible, and using the Camp Swift survey as a primary reference. Their environmental, archaeological, and historical background investigations (Skelton and Freeman 1979) will not be duplicated here but will be augmented by data pertinent to the CPS survey.

\section{ARCHAEOLOGICAL BACKGROUND}

The file search at TARL indicates sporadic and spotty archaeological activities in Bastrop County, beginning in 1953 with work at 41 BP 1 by T. N. Campbe11 and E. B. Jelks. Two burials were found associated with ceramic sherds and Scallorn arrow points of the Late Prehistoric time period.

Various amateurs have reported sites, mostly concentrated along the Colorado River, but very little usable archaeological data resulted from these early reports.

The University of Texas Archeological Society recorded sites from 1962 to 1968, leaving notes and manuscripts by Ken Brown, Thomas R. Hester, and Jim Malone on file at The University of Texas at Austin. One of their sites was a burial site near McDade, 41 BP 43, and E. Mott Davis has filed a statement indicating that the two burials were aboriginal; due to bulldozing and pothunting, the association of Perdiz and Scallorn arrow points with the burials is only tentative. 
This page has been

redacted because it

contains restricted

information. 
The Texas Archeological Survey, The University of Texas at Austin, performed limited surveys of portions of Camp Swift (Dibble 1976; Dillehay 1979) but found no time-diagnostic artifacts.

The Camp Swift survey of Skelton and Freeman (1979) is the first 1arge-scale archaeological project in the county. It was a Texas Archeological Survey project conducted for the Lower Colorado River Authority in connection with the development of lignite mining. The scope was sufficient to provide a comprehensive archaeological and historical assessment of the area; 42 prehistoric and 43 historic sites were identified. Valuable data on settlement patterns were obtained but, in common with previous Bastrop County surveys, prehistoric time-diagnostic artifacts were meager, with only two Late Archaic projectile points (Montell and Marshall) recovered.

Our literature search uncovered two publications not mentioned in Skelton and Freeman (1979). Clark (1968:6) briefly summarized the results of a 1966 survey of 13 Bastrop County sites. Data from two of these, 41 BP 48 on the Colorado River and 41 BP 55 on Big Sandy Creek, are pertinent to the CPS survey. A Late Archaic dart point (Marshall) and a triangular mano were found at 41 BP 48 , while a single sherd of Leon Plain bone-tempered pottery and a Perdiz arrow point (Late Prehistoric) were found at 41 BP 55. Duke (1977:15) reported a very large and prolific terrace site (41 BP 79) near Smithville in southern Bastrop County. Projectile points covered a wide time spectrum, including a good representation of the Pre-Archaic (Sollberger and Hester 1972) or San Geronimo time period (Weir 1976) not previously reported in Bastrop County. Duke (1977) also labeled the site as a "possible" Paleo-Indian site based on one resharpened "Plainview Golondrina" dart point. A computer-assisted classification program (Kelly 1976) places the point well inside the parameters of the Golondrina type. This is the second "possible" Paleo-Indian site reported, the other being 41 BP 51 (Skelton and Freeman 1979).

To date, no stratified sites with long cultural sequences or with organic radiocarbon dating material have been found to establish the needed chronological sequence.

\section{CPS STUDY AREA A}

Study Area A consists of approximately 1900 acres owned or leased by CPS north of McDade and Butler, with approximately 300 of these acres in Lee County. It is surrounded by an area of potential interest to CPS of about the same size that, if determined to be affected, will be the subject of a later survey.

The area lies in the Texan Biotic Province (Blair 1950) and geographically is part of the Texas Gulf Coastal Plain. This northeastern portion of the county lies in the secondary forest and woodland, while Elgin, a few miles northwest, is in the fertile blackland prairie. The soils are red sandy clay and sand and are somewhat marginal farmlands. Today there are only a few corn and maize fields under cultivation, and large areas have reverted to brush and post oak. Some of these wooded areas are difficult to penetrate on foot, as there are no cattle or deer trails through them. The principal industry is brick and pottery making, with Butler being a company town whose products have been known throughout central Texas since the 1870s. 
Bryant and Shafer (1977), using fossil pollen from peat bogs in adjoining Lee County, have determined that the paleoenvironment over the past 3000 years was characterized by savanna grasslands, with trees confined to the riparian zones and upland clusters.

The principal drainage is Big Sandy Creek, which originates immediately west of the survey area and drains southwest to the Colorado River. Willow Creek originates in the northern portion of the area and drains northeast into Middle Yegua Creek, which in turn drains east into the Brazos River. These creeks would have been utilized by aboriginal inhabitants between the Colorado and Brazos Rivers.

The Yegua Knobs, a chain of small steep hills in a rugged, little-disturbed landscape, can be seen to the northeast from any clear point in the area. Local hunters say that this is the only good hunting area left in the county; it may have been an important hunting area for local Indians in prehistoric times. It was famous as an outlaw refuge in the period 1862-1883 (Moore 1973; Bishop 1965).

The plentiful but poor-quality lithic resources found in the Camp Swift area (Skelton and Freeman 1979:7) do not occur in the CPS area; however, scattered Uvalde Gravels and silicified wood were found. It was noted at Camp Swift (ibid.) that Uvalde Gravel outcrops clustered about the 450-foot elevation level, so their scarcity in Study Area A may be explained by the fact that the lowest elevation is above 500 feet. Field experiments in knapping the lithic in the CPS area indicated that the Uvalde Gravels fractured erratically because of numerous inclusions and the silicified wood was coarse and fractured along the grain. Artifacts of fine quality chert would be dependent on chert from outside the area.

\section{METHODOLOGY}

The survey area was divided into eight zones (Fig. 1) which generally follow existing fence 1 ines. The map shown is taken from two USGS 15-minute topographic maps: The Elgin and Lexington quadrangles. Sites were plotted via the Universal Transverse Marcator (UTM) 1000-meter grid using a Suunto compass for triangulation. The site locations were precisely plotted to within 10 meters on 1:1000-scale CPS maps and are on file at the CAR.

Elevations are given here in feet $\mathrm{ms} 7$, and statute miles are used where the vehicle odometer was used for measurement. Sites were recorded on standard CAR site survey forms and permanently filed with the Texas Archeological Research Laboratory, Austin. Subsurface testing consisted of shovel tests sorted with a trowel.

Survey techniques employed varied with the ground cover. Fairly open zones, like I, II, V, and part of VIII, were covered by transects, with the surveyors each covering a 50-meter wide strip with a zigzag walk within the strip. Zone III is so heavily forested, with dense underbrush and leaf-mold obscuring the ground. There are neither cattle nor game trails through the area. 
Zones IV, VI, and VII are covered with second growth post oaks and grasses. The survey was concentrated on the occasional cow trail, ant bed, or erosional feature which provided views of the surface. Daily estimates were made of the percentage of ground surface visible, and a hachured map was maintained to determine the effectiveness and coverage of the survey.

The format and definitions of the Camp Swift survey (Skelton and Freeman 1979) were loosely followed to facilitate comparisons. However, see the appendix for a discussion of the senior author's survey philosophy.

\section{BP 199 \\ PREHISTORIC SITES}

Location: $666540 \mathrm{~m} \mathrm{E}$; $335910 \mathrm{~m} \mathrm{~N}$; USGS Elgin, Texas 15'; Zone I (Fig. 1). An unnamed intermittent creek drainage from north to south through the area is intersected by an erosional east to west gully. The site is 100 meters up the gully from the intersection.

Elevation: 500 to 520 feet $\mathrm{ms} 1$.

Environment: The gully and immediate area are red sandy clay and barren except for scattered grasses. The land slopes upward to the west. Post oak, weeds, and grasses are comparatively dense along the creek bottom within 50 meters to the east. There are some fairly large silicified wood remnants in the site area, some of which have apparently been altered by man.

Description: The site is a thin lithic scatter covering approximately 50 square meters, centered in the gully. No burned rock was observed closely associated with the site, although burned sandstone is found almost anywhere in the survey area, most probably as a result of field clearance through burning in historic times.

Nature of Survey: Initially, only a dart point distal fragment was noted as an isolated find. Realizing how ephemeral and scarce sites were in the area, we returned late and searched the area on hands and knees, picking up all observed artifacts.

Site Material: The dart point fragment, $32 \mathrm{~mm}$ long, was of heat-treated, fine quality vitreous dark gray chert, not native to the survey area. It is carefully flaked, with fine edge retouch, and is biconvex in cross-section. Four secondary flakes of yellowish Uvalde Gravel had large unprepared striking platforms and diffuse bulbs of percussion characteristic of soft hammer flaking. The largest flake is $43 \mathrm{~mm}$ long, with cortex on each end indicating a small cobble as the source. One flake is vitreous, with a pink color change streak through it. A "chunk" of yellowish Uvalde Gravel, $53 \mathrm{~mm}$ in the longest axis, had several testing flakes driven off one end, exposing poor fracture planes that were probably the cause of its rejection. Most of the silicified wood was of a quality too poor for tool making; however, one piece was found that had been modified to a crude chopping tool on one end and one side. It measured $82 \times 78 \times 30 \mathrm{~mm}$, and its crudeness is probably attributable to the poor flaking quality of the material. A fragment of a sandstone metate measured $85 \times 72 \times 20 \mathrm{~mm}$, and the ground face contained streaks of an unidentified matter filling the porous sandstone. 
Site Type: This is a multifunctional site where flint knapping, tool making, and possibly food preparation were occurring. While the evidence is somewhat sparse, nothing was discovered that would not be found in an Archaic period campsite of very short duration and involving very few people. The nature of the terrain and the lack of any concentration of burned rock could indicate derivation from upslope. Shovel tests revealed nothing.

Site Situation: The site is on a valley slope within 100 meters of the creek drainage.

Recommendations: The only archaeological value of this site is to indicate a continuation of the settlement pattern of camps close to drainage that was recognized by Skelton and Freeman (1979) farther downstream in the same drainage complex. No further action is recommended.

\section{LE 63}

Location: $668160 \mathrm{~m} \mathrm{E}, 336070 \mathrm{~m} \mathrm{~N}$; USGS Lexington, Texas; Zone VIII (Fig. 1). The site is in Lee County just north of the Bastrop/Lee County line. It is approximately 400 meters north of FM 696 in an erosional wash on the west edge of a maize field. Willow Creek is 150 meters down the wash to the south.

\section{Elevation: 490 feet ms 1 .}

Environment: Soil is a yellow sandy clay with scattered weeds and grasses and fairly dense oak and brush along willow Creek. Drainage is southward into Willow Creek, which in turn drains to the northeast into Yegua Creek and thence into the Brazos River. There are small pieces of hematite in the area.

Description: Five lithic fragments were found along a 50-meter stretch of the erosional feature from its start in the maize field.

Nature of Survey: A very careful search was made of the area, collecting all artifacts.

Site Material: The total collection consisted of two lipped flakes, two shattered flakes, and a chunk of exceptionaliy fine quality translucent honeycolored chert, which is not found in the survey area in raw form. A lipped flake has a multi-faceted, carefully prepared platform, and the diffuse bulb of percussion indicates billet or soft hammer flaking technique. Such flakes usually result from the making of bifaces. The chert is slick, homogeneous, and of very high quality.

Site Type: A lithic scatter resulting from implement manufacture using imported chert can be suggested for this site. We could neither prove nor disprove that the artifacts were derived from upslope. Shovel tests revealed no depth to the deposit.

Site Situation: The site is on a valley slope within 150 meters of a principal drainage. 
Recommendations: This ephemeral flake scatter indicates that aboriginal of an undetermined time period were present and were knapping flint imported from a source outside the area. It satisfies the site concept proposed in Skelton and Freeman (1979:24) and adds a small bit of information when coupled with the Camp Swift survey (ibid.:53) to ". . . the nature of human utilization of upland areas from these major watercourses." No further action is recommended.

\section{PREHISTORIC SITES OUTSIDE CPS STUDY AREA A}

Upon making local inquiries, the survey team was told that John Weaver was knowledgeable of the local history, and he was contacted at his home on Pleasant Grove Road. He has a large collection of arrow and dart points and volunteered to show us the three sites from which they were collected. As a matter of course we recorded these sites, 41 BP 204-206, and photographed part of his collection. 41 BP 204 is within CPS Study Area B, while 41 BP 205 and 41 BP 206 are immediately west of it.

\section{BP 204}

Location: $665940 \mathrm{~m} \mathrm{E} ; 336056 / \mathrm{m} \mathrm{N}$; USGS Elgin, Texas; CPS Study Area B adjacent to Zone V (Fig. 1). The site is located on a hillside 800 meters south of PTeasant Grove Road on the east side of Big Sandy Creek. W. D. Behrend is the 1 andowner.

\section{Elevation: 510 to 520 feet $\mathrm{ms} 1$.}

Environment: The hill is of red sandy clay soil with post oaks, grape vines, grasses, and weeds. Approximately 200 meters upstream to the north is a flowing spring, which is the origin of the flowing water in Big Sandy Creek. The Big Sandy Creek drainage originates 1000 meters north of the spring.

Description: Lithic debtiage, burned sandstone, and hematite pebbles are thinly scattered over an area of approximately 400 square meters.

Nature of Survey: The area was walked over, and a small selective collection was made of the chert debitage.

Site Material: The sample contained secondary and interior flakes with prepared faceted platforms and unprepared cortex platforms. Unifacial flaking on a nodular chunk of chert has formed a crude scraping tool. The chert was all local, rather poor quality Uvalde Gravel, with an occasional flake firealtered to pink, probably part of deliberate heat treatment to improve the knapping quality. An unusual find was one potsherd of burnished blackware. Under magnification the "temper" turned out to be a sand paste rather than the more common bone temper normally found in central Texas pottery. Mr. Weaver has a small collection of dart points from this site, mostly belonging to the Late Archaic period (Fig. 2,a); one Perdiz point is included.

Site Type: This is a multipurpose campsite of the Late Archaic and Late Prehistoric time periods. 

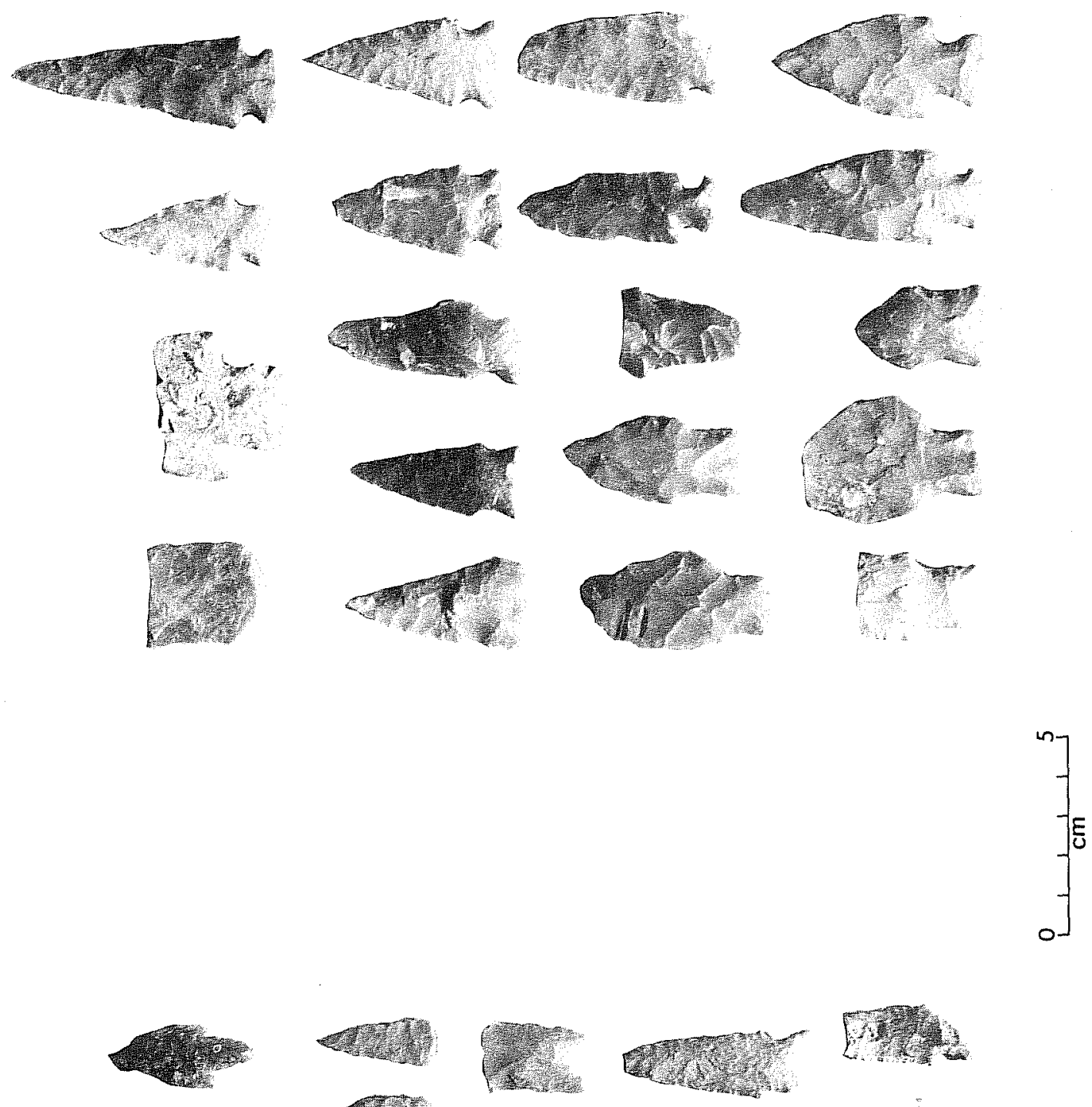

0 离

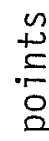

ค

穴

음

F

$\stackrel{9}{ \pm}$

톤

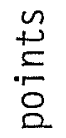

10

官
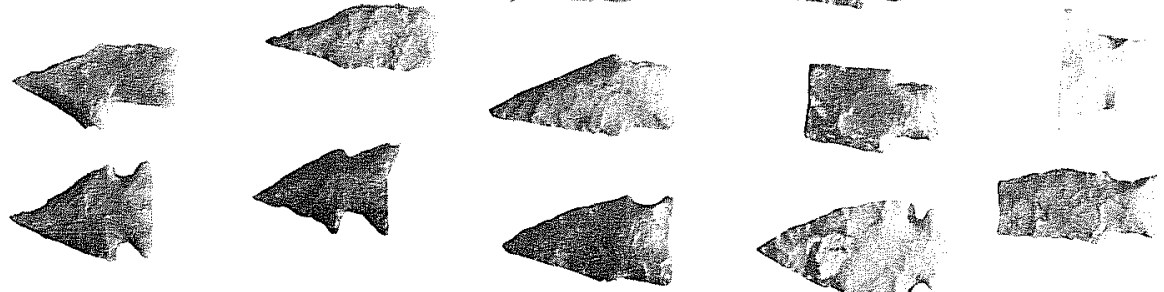

4f

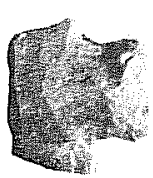

6
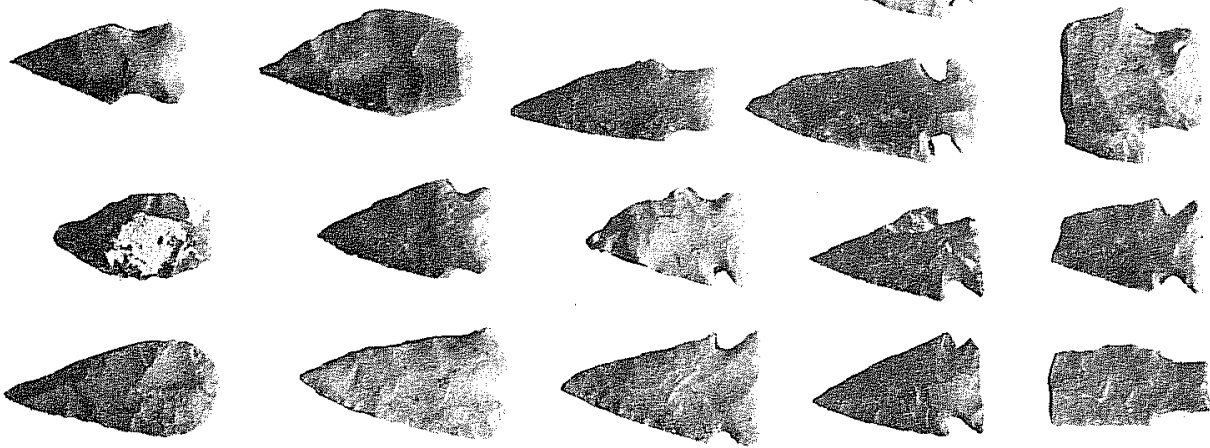

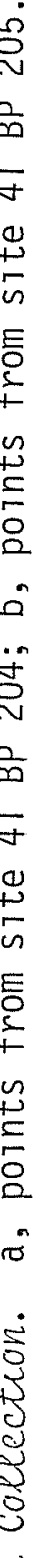

广

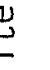

空

$\stackrel{3}{5}$

.

3

5
5
$\frac{3}{3}$
3
3
$\frac{3}{3}$

N

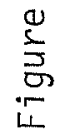


Site Situation: The exposed portion of this site is on a gentle slope near the top of a hill. It is within 50 meters of Big Sandy Creek and downstream only 200 meters from the permanent water source of the creek in an ideal "overlook" camping locality.

Recommendations: It seems likely that the best preserved subsurface part of this site is on the flat hilltop immediately north. Slight erosion seems to have uncovered only a portion of it downslope. The chance for stratified deposits is slim because the sandy soil has probably been churned up by cultivation earlier this century and by the natural erosional forces that operate in this area. However, it is the most potentially important site so far in an area of known CPS interest. If CPS proceeds with plans for Study Area B, it is recommended that 41 BP 204 be tested in order to make a better assessment.

\section{BP 205}

Location: $665330 \mathrm{~m} \mathrm{E}, 3359680 \mathrm{~m} \mathrm{~N}$; USGS Elgin, Texas; (Fig. 1). The site is immediately west of CPS Study Area B, 200 meters west of Big Sandy Creek and 800 meters south of Pleasant Grove Road on the eastern slope of a hill. $\mathrm{Mr}$. Weaver owns the land.

Elevation: 510 to 520 feet ms 1 .

Environment: The site is in a fallow field with red sandy clay soil. Corn and maize were the last crops.

Description: An area estimated at 2500 square meters contains burned sandstone rock and chert debitage.

Nature of Survey: Mr. Weaver escorted us, and a grab sample of the chert was picked up in a random walk across the site.

Site Material: The basal portion of a dart point was found. The tip was missing, one edge was straight with the other slightly concave, and the concave base had corner notches at angles of 45 degrees. The workmanship is excellent, and the chert is the local Uvalde Gravel, with a yellow color altered to pink by heat treatment. Except for the concave base, it would fit into the Marcos classification (Suhm and Jelks 1962:209). A thick flake of heat-treated chert has carefully prepared striking platforms and is either a bifacing failure or a crude scraper. Five out of the 14 flakes picked up have the pink tint and vitreous surface of deliberate heat treatment. Al1 are of Uvalde Gravel and, except for one large lipped flake with a carefully prepared striking platform, all have small unprepared striking platforms and small diffuse bulbs of percussion. Mr. Weaver found a cache of five large biface quarry blanks (Fig. $3, b$ ) on the southern edge of the site. A similar cache of 13 large bifacial "blades" was reported near Bastrop at site 41 BP 89 (Prewitt and Skelton 1979). Caching of good imported 1ithic materials was probably fairly common in this area of scarce or poor quality lithic resources. Two of the quarry blanks have been heat treated, evidencing the characteristic (for the chert in this area) pink color change and vitreous surface. All are skillfully thinned using billet flaking techniques. Three have had fine secondary flaking of the edges and may have been used as cutting or scraping tools, although no wear marks were visible to the eye. 

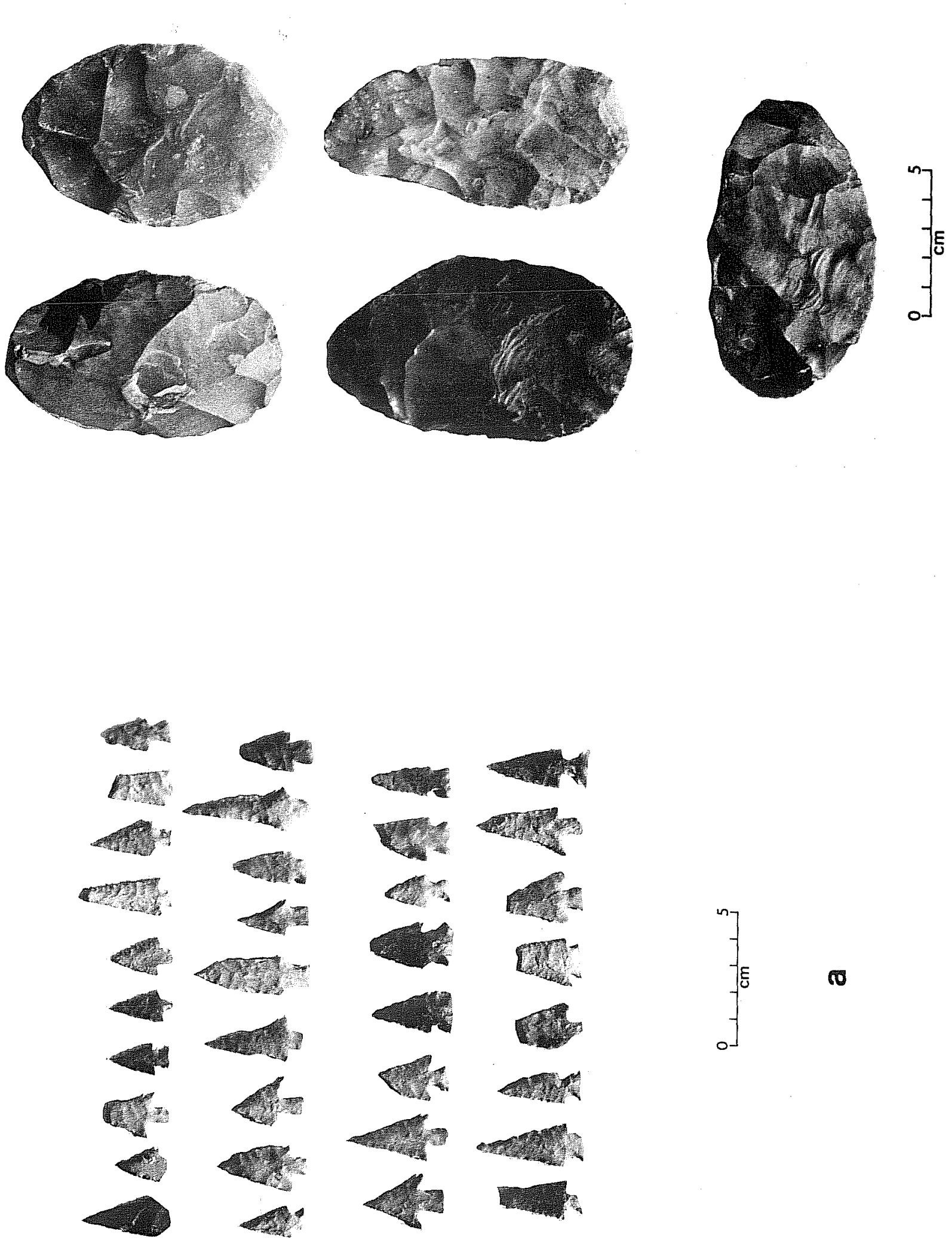

10

คั

몽

$\bar{\sigma}$

$\stackrel{\infty}{+\infty}$

o

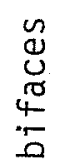

产

อ

$\ddot{\circ}$

옹

$\bar{\sigma}$

$\stackrel{9}{+}$

E.

$\stackrel{4}{+}$

욤

ro

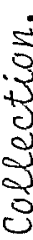

ई

志

$\dot{m}$

号 
Mr. Weaver has an extensive collection of dart points from this site (Fig. 2,b). The point types are predominantly Late Archaic, with Dare and Ensor most numerous, and Palmillas, Marcos, Williams and Morrill represented.

Site Type: Multifunctional campsite, predominantly of Late Archaic date.

Site Situation: The site is on a valley slope overlooking Big Sandy Creek and the permanent water source that originates the present flowing water of the creek.

Recommendations: This site could provide valuable information on the prehistoric period of interior Bastrop County. It is entirely possible that discrete stratified areas exist within this large site which might provide some ordering of the presentiy unknown artifact sequence in the county. The site is, however, outside the presently known CPS area of interest

\section{BP 206}

Location: $665840 \mathrm{~m} \mathrm{E}, 3359450 \mathrm{~m} \mathrm{~N}$; USGS Elgin, Texas; (Fig. 1). The site is on the southern hillside below the crest of a gentle hill, 125 meters north of Pleasant Grove Road and approximately 100 meters east of Big Sandy Creek. It is on Mr. Weaver's property.

Elevation: 510 to 520 feet $\mathrm{ms}$.

Environment: The soil is red sandy clay and presently fallow. The site is approximately 250 meters upstream from the permanent water source and provides a fine overlook of the Big Sandy Creek valley.

Description: An area on the slope of the hill, estimated at 1000 square meters in size, contains chert debitage, burned sandstone, and hematite. Mr. Weaver owns the land and lives just across Big Sandy Creek from the site. He has collected projectile points off this site for many years and still does so after every heavy rain.

Nature of Survey: The site was briefly walked, and a grab sample of chert debitage was col1ected.

Site Material: A multifaceted core, $78 \times 47 \times 36 \mathrm{~mm}$, was found. The size of the flake facets would indicate that the removed flakes would be appropriate for the manufacture of arrow points. The chert is fairly poor quality buffcolored Uvalde Gravel, with numerous small brown inclusions.

One hinge-fractured flake had been used for the manufacture of a nearly completed arrow point. The material is lustrous pearl-gray top quality chert not local to the area. Two other flakes of this material had faceted prepared platforms and very diffuse bulbs of percussion, representing probable pressure flaking technique. Four flakes of good quality white chert also have very small platforms and diffuse bulbs of percussion. Four shattered flakes retained some cortex surface and were of the prevalent local Uvalde Gravel, yellow in color. Three flakes with varying shades of buff to dark red were also of the local poor quality chert. 
Site Type: It seems to be a "pure" multipurpose Late Prehistoric site. In Mr. Weaver's collection, Scallorn and Bonham arrow points are predominant, with Bassett and Perdiz minimally represented (Fig. 3,a; Suhm and Jelks 1962). About half the chert from the small sample was brought into the site from elsewhere. This site is located very near the dividing line between the drainages of the Colorado and Brazos Rivers, but we cannot, at this time, ascertain the origin of this exotic chert.

Recommendations: Despite Mr. Weaver's long-term collecting from this site, it still has the potential to provide badly needed archaeological data from what may be a single component Late Prehistoric site. There is a good chance that the site extends to the top of the hill from which nothing has yet eroded, possibly permitting subsurface testing to find undisturbed deposits. If CPS becomes interested in this area, subsurface testing is recommended to determine if the site warrants nomination to the National Register of Historic Places.

\section{PREHISTORIC SITE SUMMARY}

Only five sites were found during this survey, two in Study Area $A$, one in Study Area B, and two immediately west of Study Area B. The two in Study Area $A$ were ephemeral and too disturbed for firm placement in specific archaeological periods. The permanent recording of these sites has been accomplished and no further action is recommended.

The finding of a single potsherd at 41 BP 204 in Study Area B is a rather rare occurrence, this being only the third ceramic-bearing site so far recorded in Bastrop County. The others were 41 BP 1 (Campbell and Jelks 1953) and 41 BP 48 (Clark 1968:6). The data recorded for 41 BP 205 coupled with the collection of Mr. Weaver, indicates high archaeological potential for this very large site.

41 BP 206 seems to be a "pure" Late Prehistoric site and, in addition to a projectile point series, might be expected to yield other tools that are characteristic of the Late Prehistoric period only.

\section{COMPARISONS WITH THE CAMP SWIFT SURVEY}

This survey, while on a much smaller scale than the Camp Swift Survey (Skelton and Freeman 1979), still provides a few interesting observations and theories that are complementary. The 11 "Cobble Procurement Camps," 26\% of the Camp Swift sites, have no counterpart in the CPS area. They were associated with Uvalde Gravel outcrops clustered about the 450-foot level at Camp Swift, while the entire CPS area is above 500 feet and the gravel outcrops are probably still buried. We can predict or theorize that, if Big Sandy Creek is explored farther south in the CPS area, "Cobble Procurement Camps" should be found beginning about a mile north of Butler, where erosion first exposes the 450-foot elevation contours.

The Camp Swift survey team found 38 to 42 sites within 200 meters of the major creek drainages, while the CPS survey recorded all five sites within 200 meters of the creeks. This would represent $91 \%$ of the combined surveys and suggests that future initial or reconnaissance-level surveys in the interior areas of Bastrop County might concentrate their efforts along strips within 200 meters of the creek in terms of greatest time and cost effectiveness. 
Neither survey located any sites earlier than the Late Archaic time period. There is the prior record of at least one Pre-Archaic site (Duke 1977) and another possible Paleo-Indian site (the Pease site, 41 BP 51) within the county.

Both surveys report imported 1 ithic resources, and the location of both areas on the divide between the Colorado and Brazos River drainage presents an interesting future problem, beyond the scope of the present CPS study, to determine the origin of the exotic cherts.

Neither survey has resolved the problem of artifact sequences so badly needed to get a clear picture of the prehistoric chronology, but both have produced sites that should be tested for such data. Now that one milligram of carbon will theoretically yield an accurate radiocarbon date (Pavlish and Banning 1980), the chances of dating sites in Bastrop County are vastly improved.

\section{PREVIOUS HISTORICAL WORK IN THE AREA}

Historical references to the survey area are apparently very 1 imited. Little can be added to the historical summary prepared by Ske1ton and Freeman (1979) except a short summary of the lurid 1863 to 1883 period of lawlessness in the McDadeYegua Knobs area of Bastrop and Lee Counties. Source material for the following summary was from local informants and from Moore (1973) and Bishop (1965).

The Yegua knobs are a series of steep hills extending from three miles east of McDade northward into Lee County. This has always been a wilderness area and, according to local lore, was used by raiding Comanches to coordinate their raids with smoke signals. These knobs are clearly visible from any unobstructed point in the CPS survey area.

McDade was a small trading post in 1840 and, along with Elgin, only became incorporated as a town in 1871 with the arrival of the Texas Central Railway. The area was badly disrupted by the Civil War, and organized outlaw groups settled in the area, particularly in the knobs along Yegua Creek. These outlaws were called the Dodgers, and their principal occupation was cattle rustling, made easy by the thousands of unbranded cattle that ran wild as a result of wartime abandonment. The Dodgers were either followed by or evolved into the Notchers or Notch Cutters because of their custom of filing notches in their guns for every man they killed. They were well organized, sharing in the prosperity that came to McDade with the raitroad's building payrolls and from its status as a cattle railhead. There were never enough lawmen in the area to bother them very much and they were rather casual about killing, in one case murdering a man for the clothes he wore. Citizens brave enough to testify against them were ambushed. A range war developed when ranchers attempted to protect their herds by hiring fighters. Two dead Notchers were found dressed in green cowhides bearing the 01 ive brothers' brand and, in retaliation, 15 to 25 Notchers attacked the 01 ive ranch house at night and set it afire, with casualties inflicted on both sides.

Two strangers were found hanged in 1876, apparently for just their horses and saddles, as their pockets were full of money. Citizens organized a secret vigilante committee, and in 1877 removed four Notchers from a Saturday night dance and hanged them. Several Notchers left the county after that but senseless murders 
resumed, climaxing in 1883 when a Lee County deputy sheriff was murdered at night in McDade while investigating the robbery-murder of two storemen from a small settlement nine miles from McDade. On Christmas Eve, the vigilantes rode up to the Rock Front Saloon (now a museum), called out three selected Notchers, mounted them on their horses, and hanged them at a location about a mile out of town. Christmas morning six Notchers came in for a drink at the Rock Front, heard what had happened to their kin, and decided to kill Tom Bishop and George Milton, whom they suspected were vigilante leaders. Despite the odds, Bishop and Milton survived unscathed, killed two Notchers (a third died of wounds the next day), and chased one off with 17 wounds.

Governor Ireland established martial law in McDade, but the citizens had a church meeting and voted on a list of Notchers whom they considered to be the worst, and gave them the option of leaving the country or being hanged. One assumes that they left, as there were no more hangings and relative peace returned to McDade and the Yegua Knobs.

Butler has always been a company town, with Butler bricks widely distributed throughout south Texas. The clays of this area are fine for pottery making, an industry practiced since the 1870s in Butler, McDade, and Elgin (Moore 1973).

\section{HISTORIC SITES}

\section{BP 200}

Location: $665700 \mathrm{~m} \mathrm{E}, 3357430 \mathrm{~m} \mathrm{~N}$; USGS Elgin, Texas; Zone I (Fig. 1). FM 696 has been improved at this point, eliminating two right-angled turns. The site is immediately northwest of the highway, hidden by brush in an oak grove. A modern house is approximately 75 meters northeast on a dirt crossroad.

Site Type: Morgan Chapel Cemetery is not 1isted in the 7ist of Bastrop County cemeteries by Moore (1973:258-261).

Description: There has been no maintenance of the cemetery for a long time, and it was necessary to cut away dense weeds and brush to identify the graves. We located only eight graves, but local informants, Mrs. John Casey (nee Wolfe) of Elgin and Mrs. Norris W. Hoerman of McDade, stated that there were many more

Hispanic graves there and that some had been destroyed or covered by the alteration of FM 696.

Six of the eight graves are located in two ornamental iron-fenced rectangles, and the one closest to the highway has a nameplate on a gate in the southwest corner labeled "STEWARD IRONWORKS, CINCINNATI, OHIO," (Fig. 4,a). The second enclosure had no gate, but the ornamental ironwork was identical. Some grave markers are out of place and leaning against the fence, with one leaning against a large oak tree outside the first fenced area. The cemetery boundaries were not determined because of the ground cover. 01der unmarked.graves might be 10cated if the brush were cleared.

Grave Descriptions: The eight graves are described in the alphabetical order shown in Fig. 5 (Morgan Chapel Cemetery Plan). 
A. William F. Cruse Co. C WALLER'S REGT. TEXAS CAV. C.S.A. (no date) (Fig. $4, \mathrm{C}$ ). The marble headstone is adorned only with the Gothic Cross.

B. ANNA M. CRUSE JULY 41848 JAN 101914 SHE IS AT REST IN HEAVEN (Fig. $4, \mathrm{~b})$. The headstone is large ornate marble set into a marble base with the family name CRUSE. Ornaments are doves and elaborate pearly gates. A footstone has her initials, A.M.C. Frank Creel of Elgin is her grandson, while Mrs. Norris $W$. Hoerman of McDade is her great granddaughter and seems to be the person most interested in preserving the cemetery.

C. No tombstone remains, but the grave is outlined in Butler bricks.

D. The tombstone is of marble, sma11, and has ornate scroll work. It sits in a concrete base slotted to fit. INFANT DAU. OF JOSHAWAY \& JENNIE BROWNING BORN AUG. 27, 1897.

E. This red brick and concrete crypt is unmarked and located northwest of the first enclosure.

F. A child's grave is outlined in brick northwest of grave E. The footstone is engraved D.L.J., and the marble headstone is out of its socket, leaning against a large oak tree. Ornamentation is a carved dove, and the inscription is bad7y deteriorated. DASHA LEE SON (??) OF DR. (??) M.E. JOHNSON BORN JULY 29, 1897 DIED JUNE 20, 1892. BLOSSOMED ON EARTH TO BLOOM IN HEAVEN.

G. An ornate obelisk of marble is leaning against the fence in the second rectangle. It has a socketed base in concrete and a marble footstone with C.M.M. engraved. Ornamentation is a bundle of wheat and floral decoration, top and bottom. CAROLINE M. MYERS BORN APR. 18, 1833 DIED MAR. 4, 1904 FOLD HER, O FATHER, IN THINE ARMS AND LET HER HENCEFORTH BE A MESSENGER OF LOVE BETWEEN OUR HUMAN HEARTS AND THEE.

H. The gravestone is leaning against the fence but is in good condition. It has an ornately carved floral decoration at the top. MY MOTHER IN MEMORY OF JANE IVY BORN AUG. 4, 1812 DIED JULY 10, 1891. DEAREST MOTHER THOU HAS LEFT US, AND THY LOSS WE DEEPLY FEEL, BUT TIS GOD THAT HATH BEREFT US, HE CAN ALL OUR SORROWS HEAL. YET AGAIN WE HOPE TO MEET THEE, WHEN THE DAY OF LIFE HAS FLED, WHEN IN HEAVEN WITH JOY TO GREET THEE, WHERE NO FAREWELL TEAR IS SHED. A marble footstone is inscribed with J.I.

Time Period: The dates of these interments fall between 1891 and 1914. Kel7y (1979:12) found an identically styled ornamental grave fence at Palafox, Webb County, Texas. There the two graves had death dates of 1907 and 1913, and the gate had a name plate "MADE BY THE CINCINNATI IRON WORKS." These ornamental fences from Cincinnati were apparently popular in Texas about the turn of the century.

Local informants (Hoerman and Casey, personal communication), stated that Morgan Chapel, a Methodist church, was in the vicinity, but no remnants were observed. It probably stood where the house now stands some 75 meters away. Dunbar and Biggers are two other families that have burials here. Mrs. Hoerman thinks the cemetery title is clouded, as the acreage was donated to the church. 


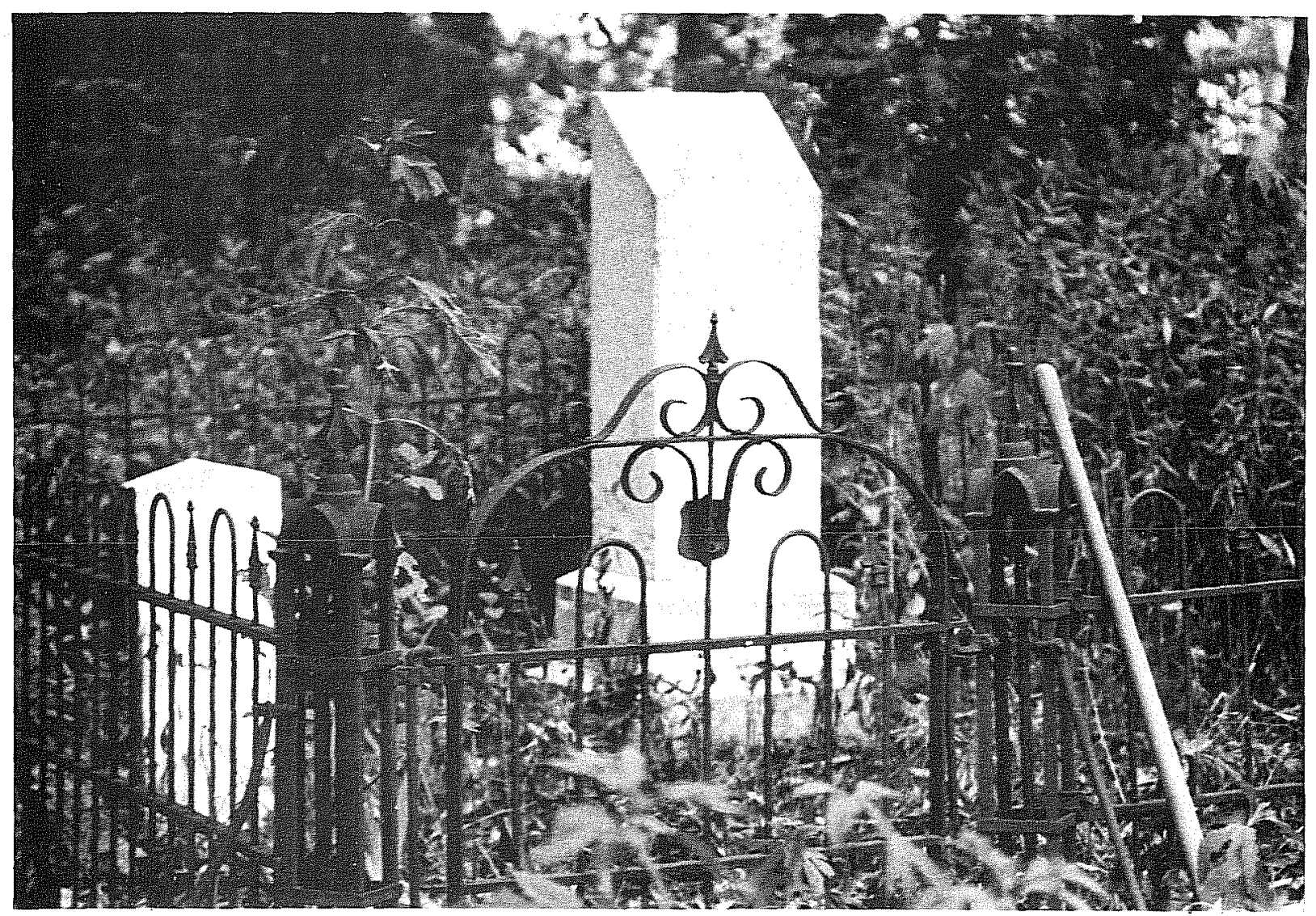

a

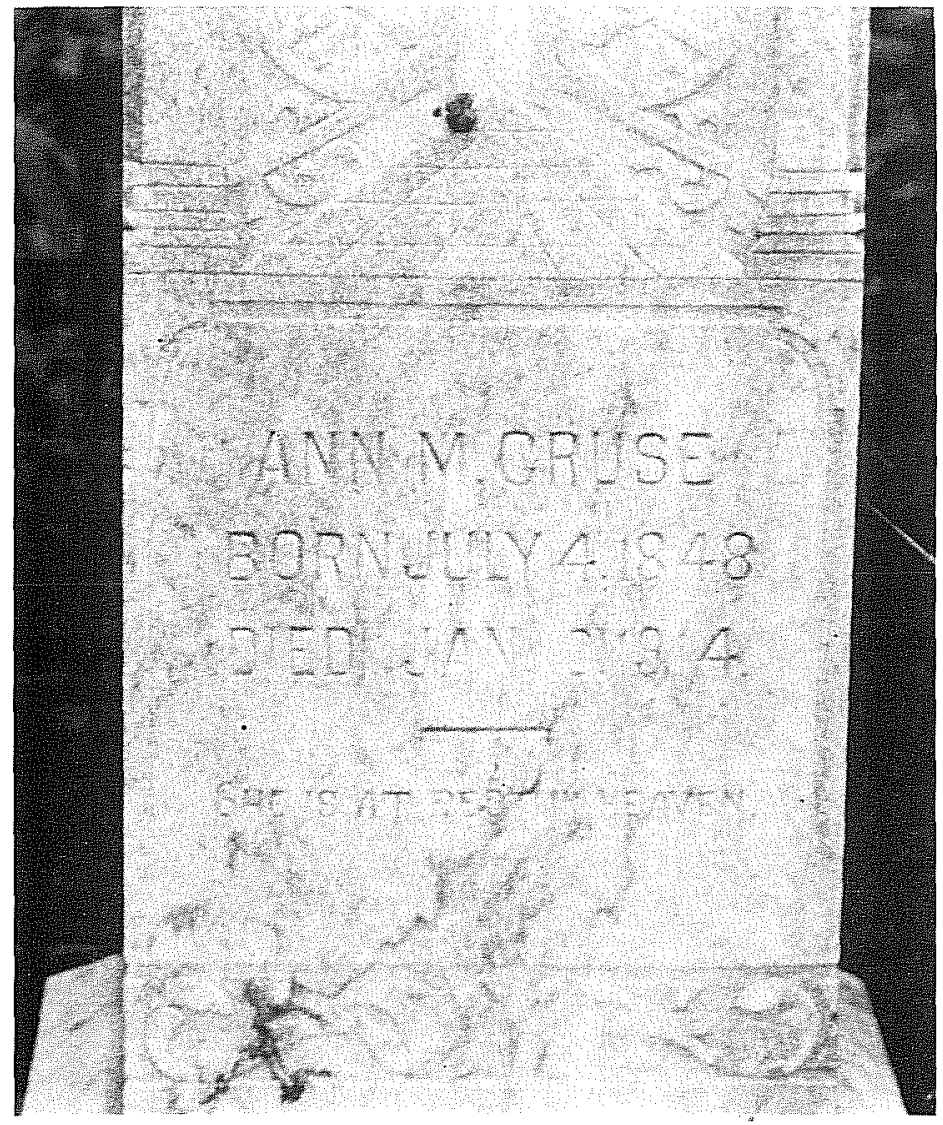

b

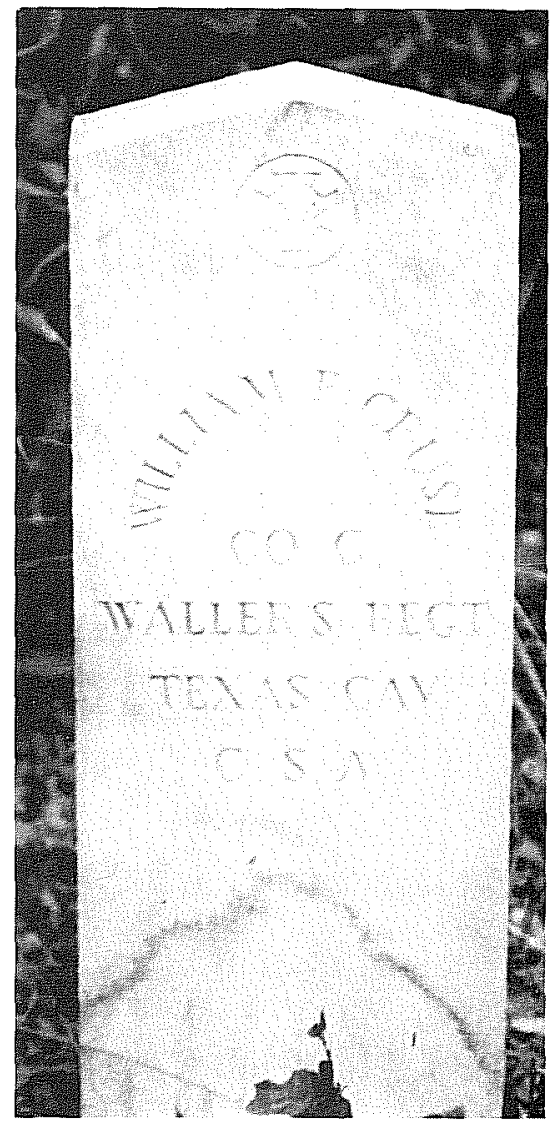

c

Figure 4. Morgan Chapel Cemetery. a-c, Cruse family graves enclosed by iron fence with gate. 


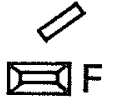

ㅁ

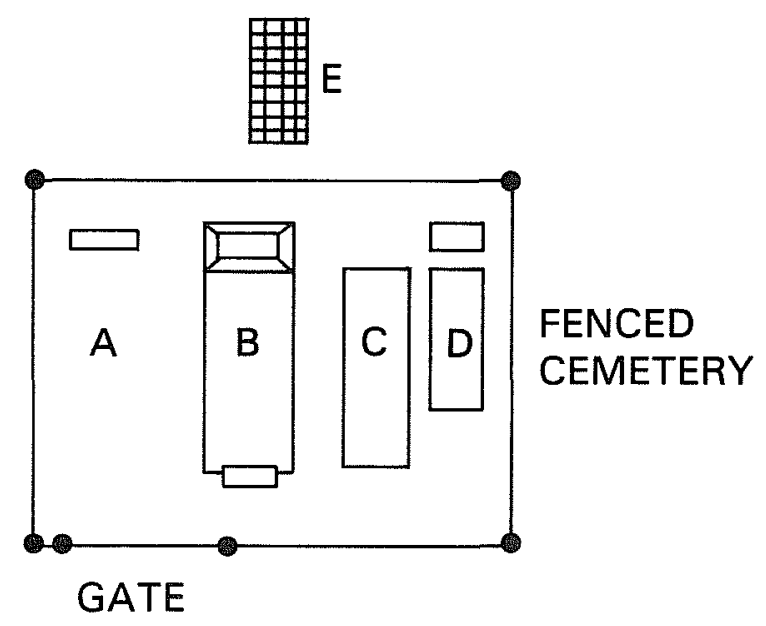

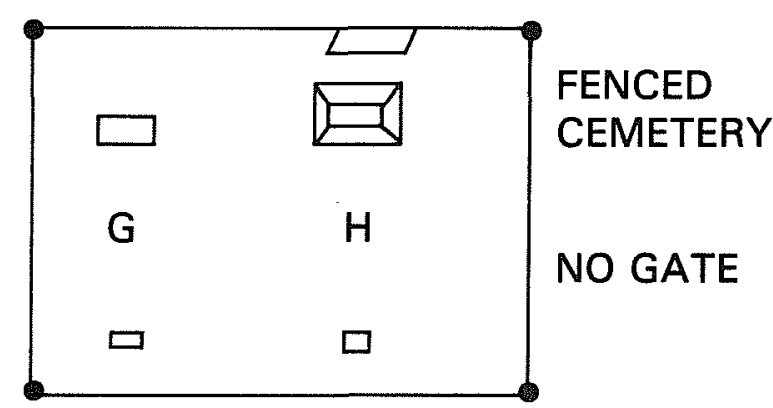
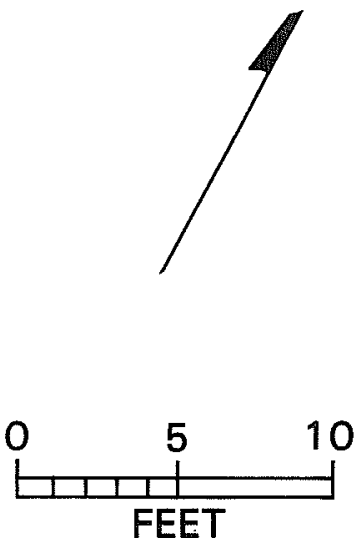

FM 696

Figure 5. Morgan Chapel Cemetery. Plan view. 
Recommendations: We could find no indications that any person of historical importance was buried here and do not recommend its nomination to the National Register. It is possible that archival research might turn up more information about the Morgan Chapel community. It is recommended that an archival search be made, particularly in the newspaper files of McDade and Elgin.

\section{BP 201}

Location: $666580 \mathrm{~m} \mathrm{E}, 3357880 \mathrm{~m} \mathrm{~N}$; USGS Elgin, Texas; Survey Zone II (Fig. 1). An ornamental stone gateway, possibly of WPA construction, is on the east side of FM 696, 2.4 miles north of the Southern Pacific tracks in Butler. The site is less than 0.2 miles east of the highway south of the entry road.

Site Type: A split-log corn crib (Fig. 6,a) is associated with the remnants of a house, with only the brick chimney made of Butler bricks still standing. The $\log$ crib consists of two structures separated by a "dogrun." Segments of a tin roof are scattered over the area. The structures are approximately four meters square, with a two-meter separation between them. One is fairly intact and is three meters ta11. There are no door jambs, but each has an opening approximately one meter above ground level. Large native ironstones, located at each corner and midway on each site, support whole log foundation runners. Split log floors lie across these runners, and the walls are split logs notched at the structure's corners. The original chinking is missing, and milled wood has been added at a later date. The original nails are square, but there are more modern round nails than square remaining. Artifacts consisted of harness parts stored in the better-preserved structure, a Mode1-T Ford steering wheel, spark coil ignition components, Ohio pottery, and 20th century bottles and glass. The house contained modern electrical and plumbing material.

Time Period: Nothing was found to indicate that the structures were any older than the beginning of the 20th century, and possibly no older than 1975. Mrs. Norris Hoerman of McDade stated that the Gordon Wolf family lived there ca. 1910-1930.

Recommendations: These corn cribs are fairly common in the area (41 BP 202203) and do not seem to meet the requirements for National Register nomination. Permanent recording seems to be adequate, and no further action is recommended.

\section{4] BP 202}

Location: $667520 \mathrm{~m} \mathrm{E,} 335680 \mathrm{~m} \mathrm{~N}$ : USGS Elgin, Texas; Survey Zone IV (Fig. 1). A dirt road runs southeast from FM 696, three miles from the Southern Pacific railroad crossing in Butler. One-half mile along this road, and located north of the road, is a farmhouse owned by CPS.

Site Type: The comparatively modern house has been added to and built around an older log cabin. There is also a split-log structure north of the house. 


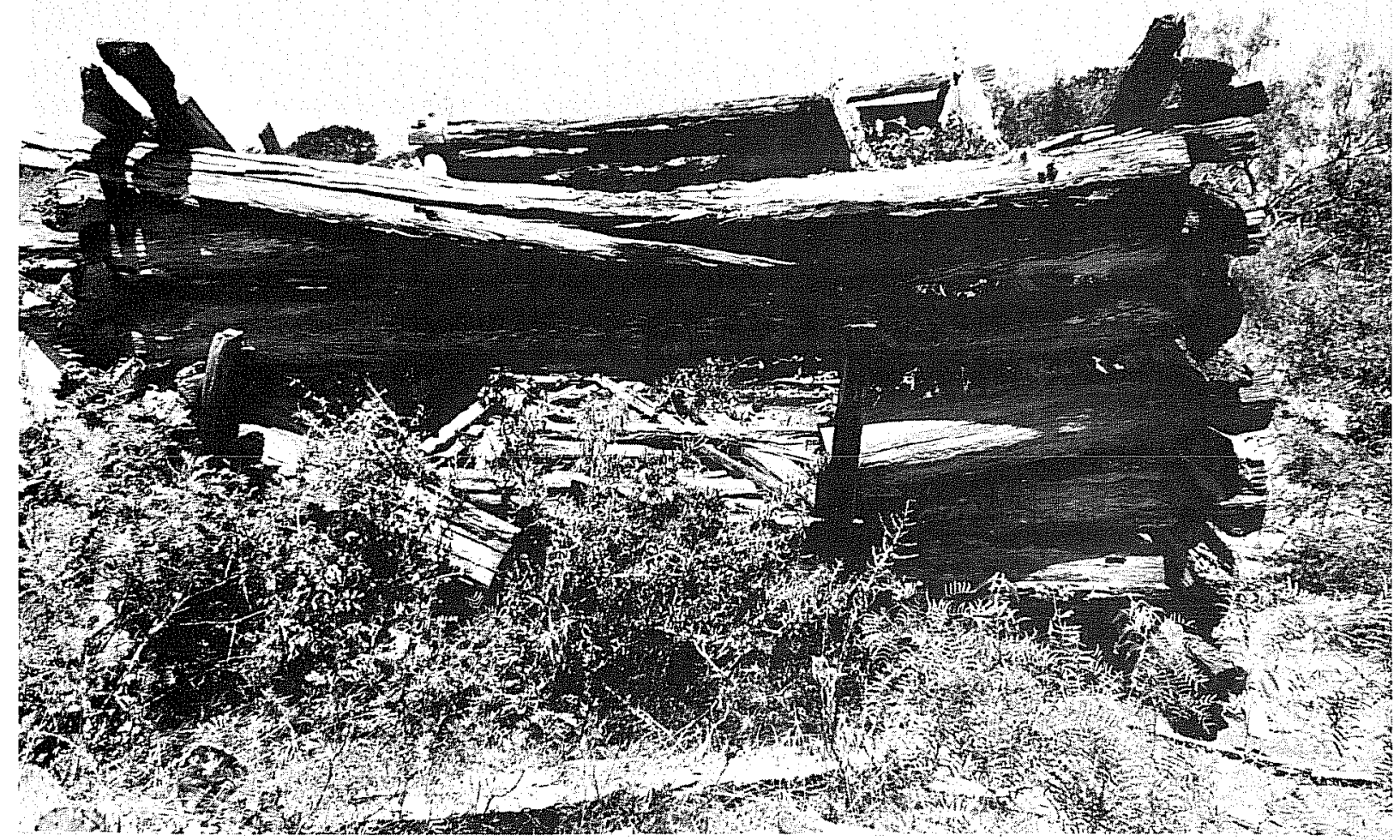

a

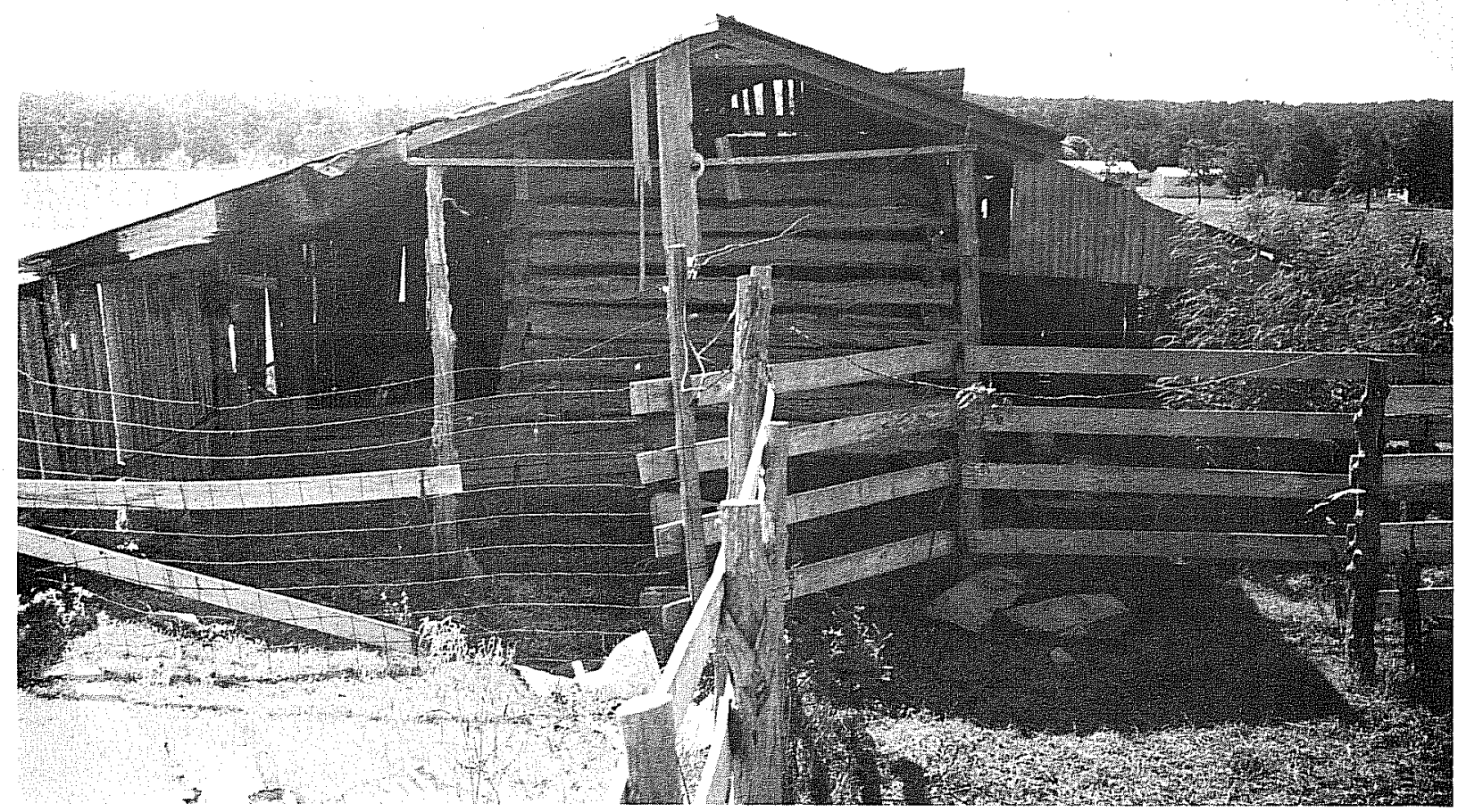

b

Figure 6. Historic Sites. a, log corn crib at site 41 BP 201 ; b, 109 corn crib at site 41 BP 203. 
Description: The log cabin has been largely absorbed by the later building and is of doubtful historical value. The split-log corncrib is very similar to that described for 41 BP 201, but is in much better condition (Fig. 7) and is still in use. If the Texas Historical Commission thinks it is worthwhile, detailed drawings could be made.

Time Period: Our local informant, Mrs. Hoerman, stated that the Hackworth family lived there ca. 1910 and that there are no surviving members of the family in the area.

Recommendations: It is very doubtful that this site meets the criteria for nomination to the National Register. It will be destroyed by the CPS mining operation.

\section{BP 203}

Location: $667420 \mathrm{~m} \mathrm{E}, 3359220 \mathrm{~m} \mathrm{~N}$; USGS Elgin, Texas; Zone V (Fig. 1). August Weisner's Bar is located on FM 696, 3.2 miles north of the S.P. crossing in Butler. North of the bar is a frame house that is reported to be 100 years $01 d$. Divided split-log cribs in good condition are north of the house (Fig. 6,b); they are very similar to those at 41 BP 201-202.

Description: The house is presently rented and not accessible. It has splitlog foundation supports, with milled wood used in the construction. According to Mrs. Hoerman, the Cruse family, mentioned in descriptions of the Morgan Chapel Cemetery, either built it or lived in it about 1890.

Time Period: No archaeological evidence was found to indicate any date earlier than that for the Morgan Chape1 Cemetery, 1890-1914.

Recommendations: The site is not believed to be of National Register quality. It wilT be destroyed by the CPS mining operations.

\section{HISTORICAL COMPARISONS WITH THE CAMP SWIFT SURVEY}

The four historical sites recorded in the CPS survey produced no archaeological evidence of occupation prior to ca. 1890. Two informants born in this area ca. 1899, Mrs. John Casey (nee Wolf) and Mrs. Norris W. Hoerman (nee Cruse), have indicated that the period from 1890 to 1930 covered the period of settlement, development, and decline of the area. This corresponds fairly well with the findings of the Camp Swift Survey (Skelton and Freeman 1979:100), where there were some slight indications of sites as early as 1870, although the big expansion occurred about the turn of the 20th century, with abandonment in 1942 with the founding of Camp Swift (ibid.:102).

The land comprising CPS Survey Area $A$ has never had sufficient resources to support large-scale plantation-type farming mentioned in Skelton and Freeman (1979:90); and it may be that, because of its marginal resources, the earlier settlers avoided the area. 


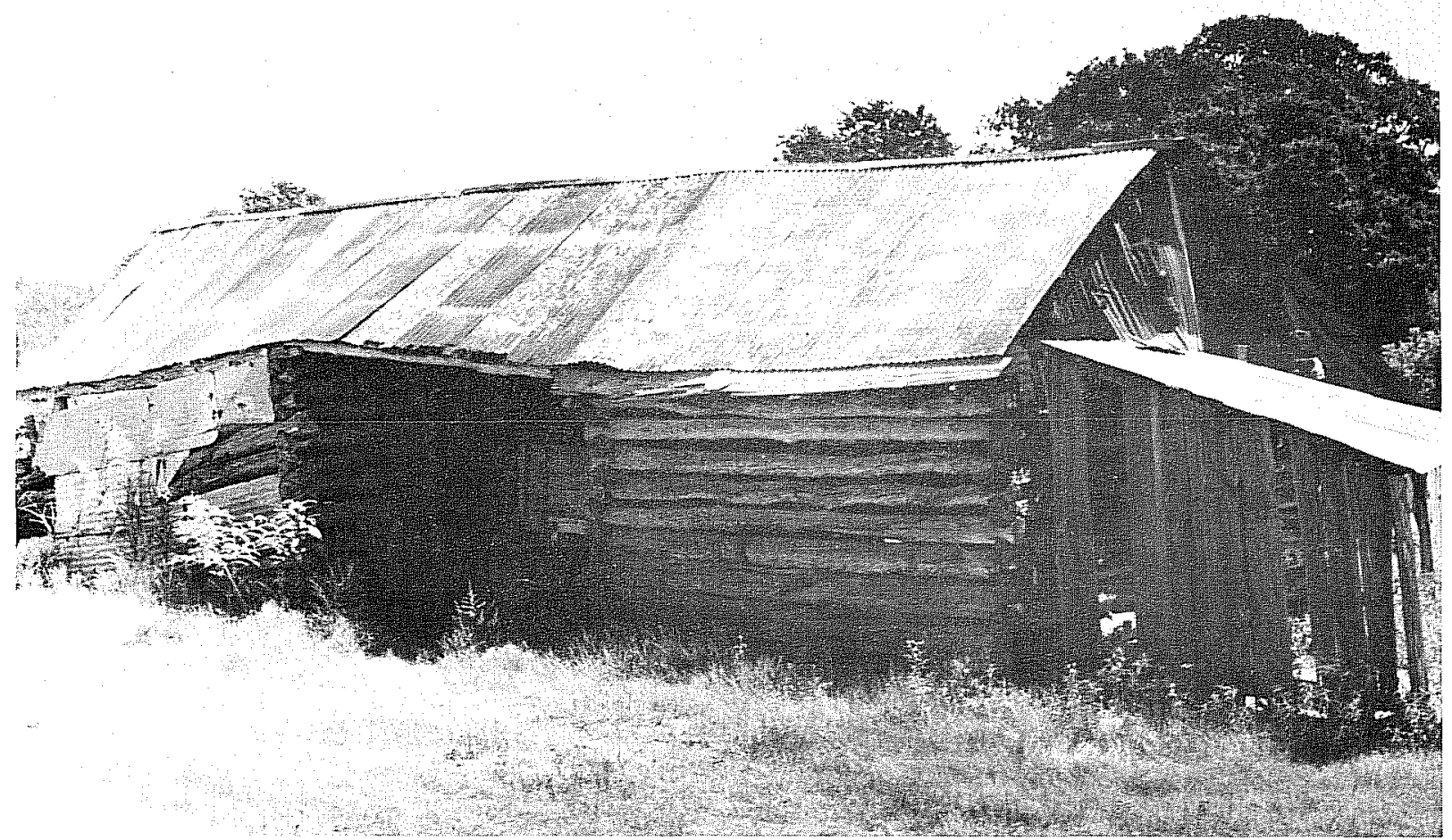

a

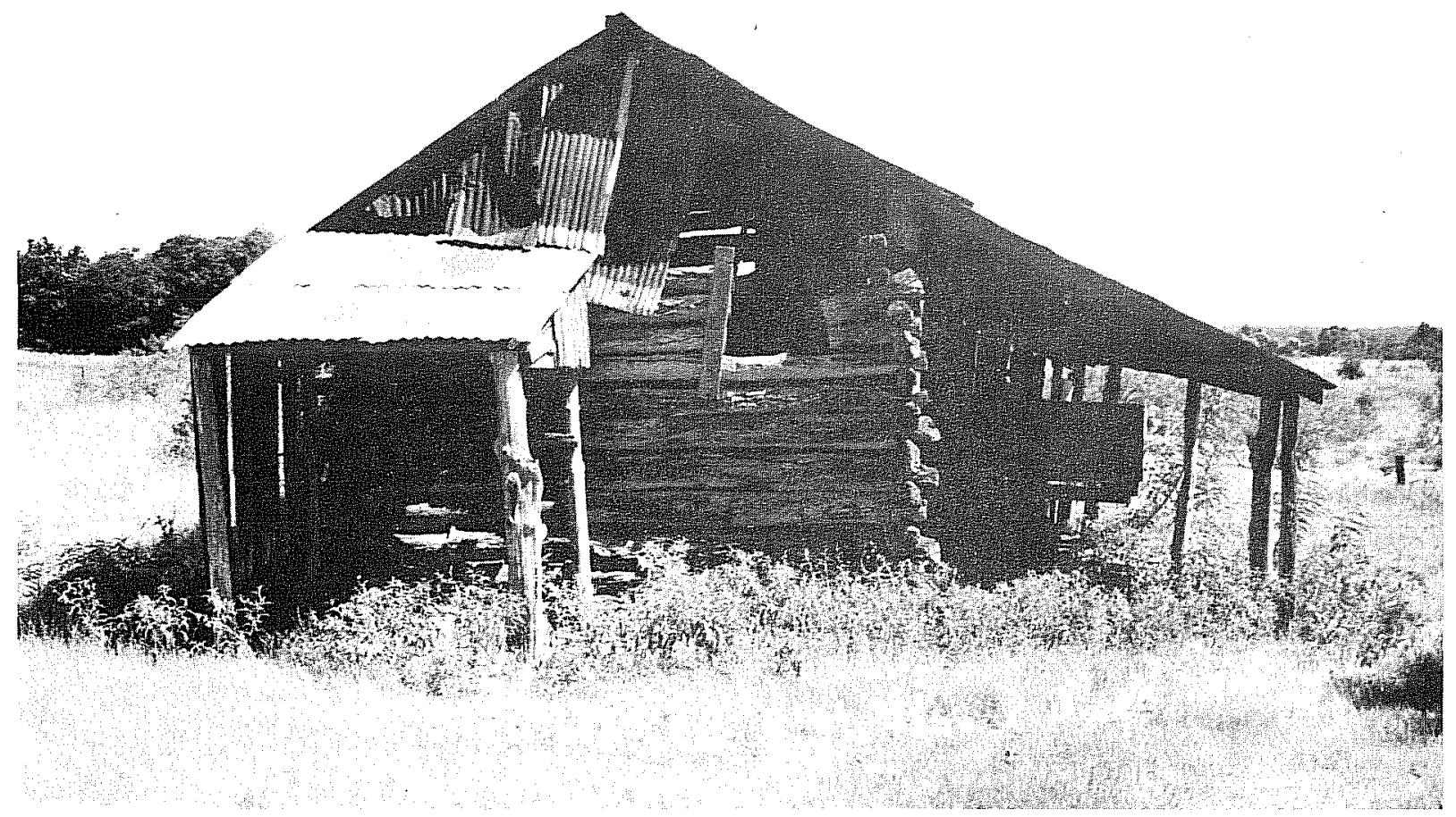

b

Figure 7. Historic site 41 BP 202. A "dog run" corn crib. a, rear view; 
The surveyors, because of theoretical precepts as to what constitutes a historical "site" (see appendix), did not record recent cisterns, scatters of "BUTLER" bricks, several occupied nondescript houses of no apparent great age or historical importance, or even Weisner's Bar, which is the precent social center of the area! Therefore no substantive comparisons can be made between the number of historic sites recorded by Skelton and Freeman (1979) and this survey.

\section{ACKNOWLEDGMENTS}

Dr. Thomas R. Hester was principal investigator and Jack Eaton was coprincipal investigator for this project. Anne Fox provided assistance in the historical portion of the report.

Erwin Roemer, Jr., shared in the field work. He accomplished all the local source interviews, and all his archival research was accomplished entirely on his own time. We are indebted to Erwin Roemer, Sr., for introducing us to the Elgin Rod and Gun Club on the banks of the Colorado River. This convivial group provided considerable insight into the history and folklore of interior Bastrop County.

Mrs. John Casey of Elgin, and Mrs. Norris W. Hoerman of McDade, were born in the survey area about the turn of the century and were able to provide an oral history of the area.

Thomas R. Hester, Carol Graves, and Mary Lou Ellis edited the report; the manuscript was typed by Carmel Yevette Graham and Jody Goode. 


\section{REFERENCES CITED}

Bishop, L. P., Sr.

1965 Shoot-out on Christmas Day. Frontier Times, July:6.

Blair, W. F.

1950 The Biotic Provinces of Texas. Texas Journal of Science 2(1):93-117.

Bryant, V. M. and H. J. Shafer

1977 The Late Quaternary Paleoenvironment of Texas: A Mode1 for the Archeologist. Bulletin of the Texas Archeological Society $48: 1-25$.

Campbe11, T. N. and E. B. Jelks

195341 BP 1. Records on file, Texas Archeological Research Laboratory, Austin.

Clark, J. W., Jr.

1968 Archeological Reconnaissance in Bastrop County, Texas. The Bull-Roarer 3(2):6-9.

Dibble, D. S.

1976 Results of an Archeological Survey of Areas to be Affected by Proposed Sanitary Landfi11, Camp Swift, Texas. Texas Archeological Survey, The University of Texas at Austin, Technical Bulletin 11.

Dillehay, T. D.

1979 An Archeological Reconnaissance of the Fayette Power Plant to Lytton Springs Transmission Line. Texas Archeological Survey. The University of Texas at Austin, Research Report 73.

Duke, P. E.

1977 Lake Thunderbird Site (41 BP 78), Bastrop, Texas. La Tierra $4(3): 15-26$.

Glassow, M.

1977 Issues in Evaluating the Significance of Archaeological

Resources. American Antiquity 42:413-420. 
Human Systems Research, Inc.

1973 Technical Manual; 1973 Survey of the Tularosa Basin, The Research Design. Human Systems Research, Inc., Three Rivers, New Mexico.

Katz, P. R.

1978 An Inventory and Assessment of Archaeological Sites in the High Country at Guadalupe Mountains National Park. Center for Archaeological Research, The University of Texas at San Antonio, Archaeological Survey Report 36.

Kelly, T. C.

1976 The Plainview-Golondrina Problem. Paper presented to the Southern Texas Archaeological Association quarterly meeting, April.

Kelly, T. C., with the collaboration of T. R. Hester

1979 An Archaeological Reconnaissance of the Palafox Mining Area, Webb County, Texas. Center for Archaeological Research. The University of Texas at San Antonio, Archaeological Survey Report 71.

Mallouf, R. J., B. J. Baskin and K. L. Killen

1977 A Predictive Assessment of Cultural Resources in Hildalgo and Willacy Counties, Texas. Texas Historical Commission, Office of the State Archeologist, Survey Report 23.

Moore, B.

1973 Bastrop County 1691-1900. Educator Books, San Ange10.

Pavlish, L. A. and E. B. Banning

1980 Revolutionary Developments in Carbon-14 Dating. American Antiquity $45(2): 290-297$.

Prewitt, E. R. and D. W. Ske1ton

197941 BP 89. Unpublished field notes on file at Texas Archeological Research Laboratory, Austin.

Raab, M. L. and T. C. Klinger

1979 A Reply to Sharrock and Grayson on Archaeological Significance. American Antiquity 44(2):328-399.

Schiffer, M. B. and J. H. House

1975 The Cache River Archaeological Project. Arkansas Archaeological Survey, Research Series 8. 
Sharrock, F. W. and D. K. Grayson

1979 Cultural Resource Management. "Significance" in Contract Archaeology. American Antiquity 44(2):327-328.

Ske1ton, D. W. and M. D. Freeman

1979 A Cultural Resource Inventory and Assessment at Camp Swift, Texas. Texas Archeological Survey. The University of Texas at Austin, Research Report 72.

Sollberger, J. B. and T. R. Hester

1972 The Strohacker Site: A Review of Pre-Archaic Manifestations in Texas. Plains Anthropologist 17(58):326-344.

Suhm, D. A. and E. B. Jelks

1962 Handbook of Texas Archeology: Type Descriptions. Texas Archeological Society, Special Bulletin 1.

Weir, F. A.

1976 The Central Texas Archaic. Unpublished Ph.D. Dissertation, Department of Anthropology, Washington State University, Pullman. 


\section{APPENDIX*}

The need for and present lack of standard archaeological terms and definitions employed by Texas archaeologists involved in cultural resource management (CRM) is a problem that must eventually be resolved by the Council of Texas Archaeologists, the State Archeologist, the Texas Historical Commission, and the various agencies involved in Texas CRM work. The definition of an archaeological site is a case in point. Most formal definitions generally follow that given in Ske1ton and Freeman (1979:24): "Any location which exhibits byproducts and residues of past human activity" and modified by "the only evidence of cultural activity not recorded as a site with isolated single artifacts found in areas where subsequent subsurface probes failed to produce any further residues." (For similar definitions see Human Systems Research 1973 and Mallouf, Baskin, and Killen 1977.) Theoretically, these definitions are so broad that two chert flakes, two stray bricks, or even several of last year's tin cans could be recorded as archaeological sites. Schiffer and House (1975:47) modify the basic statement with "Historic - prior to 1860. Prehistoric - a site had to yield a double handful of cultural material." According to Katz (1978:12): "A site is characterized by the physical remains of patterned human behavior occurring in a localized finite area, and from these physical remains postulations can be made as to the time-span involved and activities performed." Below the site level he defines "the collecting locality" as "extensive light scatterings of artifacts without associated features." The "collecting locality" is adequately located and discussed and made a part of the archaeological record without going through the formal and expensive procedure that is accorded all formally recorded "sites." There is a very real cost factor involved in formally recording, mapping, photographing, sketching, typing, duplicating, filing, collating, and mailing site reports to the permanent recording center, where much of the process is repeated, with the addition of controlling and issuing of the trinominal site designations. The Wall Street Journal recently noted that the average cost of a simple business letter had reached $\$ 100$, and the more complicated site report must involve multiples of that cost. Cost as well as significance (Glassow 1977; Sharrock and Grayson 1979; Raab and K1inger 1979) should then be carefully considered before filing site reports. Ephemeral traces without diagnostic artifacts, flake scatters (possibly derived from elsewhere), and unexceptional historical occurrences, much less than 100 years old, should not clutter up the archaeological archives. They can simply be recorded in field notes and plotted on survey maps.

Despite the preceding discussion, the two differing philosophies would make little difference in the CPS survey. One prehistoric site, 41 LE 63, would not have been formally recorded and, had the Skelton and Freeman (1979) definition been more closely followed, a cistern, several brick piles (frequently found in the area with nothing in association), and possibly two dilapidated houses that are still occupied but constructed within the past 50 to 60 years, might have been recorded as sites. 
